Formatif: Jurnal Ilmiah Pendidikan MIPA

Vol. 9, No. 2, Juni 2019, pp. 151-160

p-ISSN: 2088-351X

e-ISSN: $2502-5457$

DOI: http://dx.doi.org/10.30998/formatif.v9i2.3340

\title{
Need Analysis of Science Textbook Based Jambi Local Wisdom to Improve Students Science Literacy of SMPN 7 Muaro Jambi
}

\author{
Analisis Kebutuhan Buku Ajar IPA Berbasis Kearifan Lokal Jambi \\ untuk Meningkatkan Literasi Sains Siswa SMPN 7 Muaro Jambi
}

\author{
Jufrida \\ Universitas Jambi \\ Fibrika Rahmat Basuki (*) \\ Universitas Jambi \\ Erina Sawitri \\ Universitas Jambi \\ Elsi Afriani \\ SMPN 7 Muaro Jambi
}

Received: February 5, 2019

Revised: March 4, 2019

Accepted: March 15, 2019

\begin{abstract}
This study aims to analyze the need for science books based on Jambi local wisdom to improve student literacy at SMPN 7 Muaro Jambi. This research is a qualitative descriptive study. The subjects of this study were science teachers and 46 seventh grade students at SMPN 7 Muaro Jambi. The research data was collected by observation, interview, and questionnaire. Data analysis techniques were carried out descriptively. This study shows that 1) textbooks used in schools as a source of learning science have not integrated local wisdom and there are no scientific literacy questions, 2) students have high learning motivation and positive attitudes towards science, 3) supporting facilities including teaching materials and the science laboratory is adequate, 4) material that can be integrated with Jambi local wisdom including the science object and its observations, temperature and changes, and heat and displacement.
\end{abstract}

Keywords: analysis, science textbooks, local wisdom

(*) Corresponding Author: $\quad$ fibrikabika@yahoo.com 082175235412

How to Cite: Jufrida, Basuki, F. R., Sawitri, E., \& Afriani, E. (2019). Need analysis of science textbook based on jambi local wisdomto improve students science literacy of SMPN 7 Muaro Jambi. Formatif: Jurnal Ilmiah Pendidikan MIPA, 9 (2): 151-160. http://dx.doi.org/10.30998/formatif.v9i2.3340

\section{PENDAHULUAN}

Literasi sains merupakan kemampuan untuk menggunakan pengetahuan ilmiah, mengidentifikasi pertanyaan-pertanyaan dan untuk menarik kesimpulan berdasarkan bukti-bukti agar dapat memahami dan membantu membuat keputusan tentang dunia alami dan interaksi manusia dengan alam (OECD, 2015). Berdasarkan hasil Programme for International Student Assessment (PISA) 2015 terlihat bahwa literasi sains siswa di Indonesia masih berada pada kategori rendah meskipun terjadi peningkatan dari tahun 2012. Literasi sains Indonesia meningkat dari 382 poin pada tahun 2012 menjadi 403 
Formatif: Jurnal Ilmiah Pendidikan MIPA

Vol. 9, No. 2, Juni 2019, pp. 151-160

p-ISSN: 2088-351X

e-ISSN: 2502-5457

DOI: http://dx.doi.org/10.30998/formatif.v9i2.3340

poin di tahun 2015. Rata-rata skor pencapaian siswa Indonesia untuk literasi sains berada di peringkat 62 dari 69 negara.

Hal ini didukung pula dengan hasil dari Trends International Mathematic and Science Study (TIMSS) 2015 Indonesia terletak di posisi 44 dari 47 negara dalam kategori sains dengan skor 397. Sehingga terlihat bahwa literasi sains Indonesia secara global masih dikategorikan rendah. TIMSS adalah penilaian internasional matematika dan sains yang memantau 20 tahun tren dalam pencapaian pendidikan, bersama dengan data komprehensif tentang konteks siswa untuk belajar matematika dan sains (TIMSS, 2015).

Berdasarkan hasil studi literatur terdapat kesamaan antara permasalahan global dan lapangan yaitu berdasarkan hasil penelitian Nuraini, Rahardjo, \& Susanti (2016) terhadap kemampuan literasi sains mahasiswa di Surakarta relatif rendah pada kompetensi mengidentifikasi masalah-masalah ilmiah (30,87\%), kompetensi menjelaskan fenomena ilmiah (40,20\%), dan kompetensi menggunakan bukti ilmiah $(24,90 \%)$. Tingkat pencapaian literasi sains dicapai oleh mahasiswa di level $1(47,82 \%)$, level 2 $(33,82 \%)$, level $3(42,93 \%)$, level4 $(26,50 \%)$, level 5 (21,73\%). Nofiana \& Julianto (2017) juga menunjukkan bahwa persentase kemampuan literasi sains siswa SMP di Kota Purwokerto masih rendah pada 3 aspek literasi sains yaitu aspek konten $(53,80 \%)$, aspek proses $(44,038 \%)$, dan aspek konteks (35,088\%). Serta hasil penelitian Diana et al. (2015) mengenai kemampuan literasi sains siswa SMA dengan menggunakan instrument Service Level Agreement (SLA) dari ranah kognitif rata-rata termasuk kurang.

Padahal kemampuan kognitif merupakan kemampuan yang berkaitan dengan penguasaan ilmu pengetahuan. Selain itu juga, kemampuan kognitif menekankan kemampuan siswa dalam memahami materi pelajaran yang berupa fakta, konsep, prinsip, dan prosedur. Hal ini sejalan dengan literasi sains, yaitu literasi sains menekankan pada kemampuan mengetahui dan memahami serta setelah dilakukannya proses pembelajaran siswa dapat mengaplikasikannya ke dalam lingkungan (Yuliati, 2017).

Menurut Innatesari et al. (2015) salah satu akar permasalahan dari rendahnya kemampuan literasi sains siswa yaitu belum terintegrasinya kearifan lokal sebagai sumber belajar atau kurang diperhatikannya lingkungan sosial budaya sebagai sumber pembelajaran. Kearifan lokal dalam bahasa asing sering dikonsepsikan sebagai kebijakan setempat, pengetahuan setempat atau kecerdasan setempat. Kearifan lokal juga dimaknai sebuah pemikiran tentang hidup yang dilandasi nalar jernih, budi yang baik, dan memuat hal-hal positif (Istiawati, 2016).

Kemampuan literasi sains menjadi tanggung jawab para guru IPA. Salah satu cara untuk memperbaiki kemampuan literasi sains yaitu menggunakan buku ajar yang berbasiskan kearifan lokal. Kearifan lokal dipilih agar terciptanya pengintegrasian dalam memperoleh konsep yang dipelajari dengan nilai-nilai kehidupan yang terkandung dalam lingkungan sekitar. Selain itu menurut Suastra \& Nengah (2010) pembelajaran berbasis kearifan lokal adalah cara yang efektif dalam meningkatkan kompetensi siswa.

IPA merupakan salah satu ilmu yang membutuhkan sarana dan prasarana dalam pembelajaran. Pembelajaran IPA akan lebih bermakna apabila terdapat kesinambungan antara materi mata pelajaran dengan aktivitas kehidupan sehari-hari di lingkungan tempat tinggal siswa, yang digunakan sebagai sarana belajar. Sarana belajar yang dimaksudkan adalah sarana belajar yang mengaitkan antara sains dalam suatu topik atau tema tertentu. Siswa tidak hanya ditanamkan konsep teoritis dari materi, tetapi juga aplikasi dalam kehidupan nyata dari konsep yang telah disampaikan (Atmodjo, 1986).

Namun saat ini masih belum dijumpai pembelajaran IPA khususnya di daerah Jambi, yang melekatkan identitas budaya kearifan lokal masyarakat setempat diterapkan ke dalam pembelajaran IPA sebagai sumber belajar. Berdasarkan hal tersebut, dalam pembelajaran IPA perlu adanya bahan ajar yang digunakan sebagai perantara antara 


\section{Formatif: Jurnal Ilmiah Pendidikan MIPA}

Vol. 9, No. 2, Juni 2019, pp. 151-160

p-ISSN: 2088-351X

e-ISSN: 2502-5457

DOI: http://dx.doi.org/10.30998/formatif.v9i2.3340

materi pelajaran IPA dengan kearifan lokal masyarakat setempat seperti buku ajar. Hal ini didukung pula oleh hasil penelitian Perwitasari, Sudarmin, \& Linuwih (2016) yang menunjukkan bahwa buku ajar IPA yang terintegrasi kearifan lokal terbukti dapat meningkatkan literasi sains siswa dibandingkan dengan menggunakan buku paket biasa.

Menurut Permana (2015) buku ajar adalah media yang sangat penting dan strategis dalam pendidikan. Oleh karena itu buku ajar bersifat mencerdaskan, mencerahkan, mampu menggugah nalar, dan spiritual siswa untuk menjadi lebih kreatif serta inovatif. Seleras dengan pendapat ini, Sholahuddin (2011) menyatakan bahwa buku ajar merupakan salah satu media dalam pembelajaran yang berisi informasi materi pembelajaran, gambar-gambar dan penjelasan konsep, selain itu terdiri atas rangkaian kegiatan pembelajran yang disusun untuk membantu siswa mencapai tujuan pembelajaran.

Buku ajar memiliki dua fungsi utama, yaitu buku ajar harus dapat menjadi sumber ilmu pengetahuan dan menjadi media yang baik serta dapat membantu proses pembelajaran (Achyani et al., 2010). Untuk mendapatkan buku ajar yang sesuai maka dibutuhkan analisis kebutuhan siswa dan guru, karakteristik siswa, sarana pendukung, dan materi pembelajaran.

Analisis kebutuhan siswa dan guru diperlukan untuk mengetahui isi buku ajar yang tersedia serta mengetahui buku ajar seperti apa yang diharapkan. Analisis kebutuhan juga dilakukan untuk mengetahui kebutuhan guru dalam proses pembelajaran seperti media, metode, buku ajar, dan sarana pendukung pembelajaran. Selain analisis kebutuhan siswa dan guru, dibutuhkan juga analisis karakteristik siswa dalam pembelajaran IPA yang dimaksudkan untuk mengetahui sikap dan minat siswa terhadap pembelajaran IPA.

Selain analisis kebutuhan dan karakteristik siswa, tahap awal pengembangan buku ajar berbasis kearifan lokal jambi juga membutuhkan analisis materi untuk mengetahui materi apa saja yang bisa diintegrasikan dengan kearifan lokal Jambi. Pada proses mencapai tujuan pembelajaran juga perlu memerhatikan faktor pendukung lainnya seperti laboratorium, perpustakaan, dan ruang kelas. Analisis ini dilakukan untuk mengetahui sejauh mana peranan sarana pendukung dalam mencapai tujuan pembelajaran. Berdasarkan hal itu, penelitian ini bertujuan untuk mengetahui kebutuhan buku ajar siswa yang mengintegrasikan pembelajaran IPA dengan kearifan lokal Jambi di SMPN 7 Muaro Jambi kelas VII semester I.

\section{METODE}

Penelitian ini menggunakan penelitian deksriptif kualitatif, yaitu menganalisis hasil observasi, wawancara, dan angket kebutuhan buku ajar berbasis kearifan lokal Jambi. Penelitian ini dilakukan di kelas VII SMPN 7 Muaro Jambi dan dilakukan pada semester ganjil tahun ajaran 2018/2019. Subjek penelitian adalah guru IPA dan siswa kelas VII SMPN 7 Muaro Jambi tahun ajaran 2018/2019 yang berjumlah 46 siswa. Prosedur penelitian ini yaitu tahap pertama menyusun angket analisis kebutuhan buku ajar berbasis kearifan lokal. Angket guru terdiri atas 25 pertanyaan pilihan, serta 18 pertanyaan pilihan untuk angket siswa. Tahap kedua dilakukannya penyebaran angket terhadap siswa kelas VII serta seorang guru IPA SMPN 7 Muaro Jambi. Tahap ketiga adalah melakukan analisis terhadap angket yang telah diisi oleh siswa dan guru. Teknik pengumpulan data dilakukan dengan observasi, wawancara, serta penyebaran angket analisis kebutuhan buku ajar berbasis kearifan lokal Jambi. Teknik analisis data yang digunakan yaitu analisis deskriptif terhadap hasil observasi dan wawancara serta mencari 


\section{Formatif: Jurnal Ilmiah Pendidikan MIPA}

Vol. 9, No. 2, Juni 2019, pp. 151-160

p-ISSN: 2088-351X

e-ISSN: 2502-5457

DOI: http://dx.doi.org/10.30998/formatif.v9i2.3340

rata-rata hasil angket analisis kebutuhan buku ajar berbasis kearifan lokal yang kemudian dideskriptifkan secara kualitatif.

\section{HASIL DAN PEMBAHASAN}

\section{Analisis Kebutuhan Guru dan Siswa}

Hasil penelitian diperoleh dari instrumen berupa angket analisis kebutuhan untuk memperoleh data respon guru dan siswa terkait dengan pengembangan buku ajar IPA berbasis kearifan lokal Jambi untuk meningkatkan literasi sains siswa. Angket guru terdiri dari 25 butir pertanyaan. Aspek yang diukur dalam angket tentang respon guru terhadap pembelajaran dan buku ajar yang terdiri dari: (1) Pemanfaatan buku ajar IPA, (2) Buku ajar IPA yang digunakan telah mengaitkan pada kehidupan sehari-hari, (3) Kebutuhan buku ajar tambahan. Berikut hasil data angket guru pada Tabel 1.

Tabel 1. Hasil Data Angket Guru

\begin{tabular}{clc}
\hline No & \multicolumn{1}{c}{ Indikator } & Respon \\
\hline 1 & Pemanfaatan buku ajar IPA & $100 \%$ \\
2 & $\begin{array}{l}\text { Buku ajar IPA yang digunakan telah } \\
\text { mengaitkan pada kehidupan sehari- }\end{array}$ & $100 \%$ \\
& $\begin{array}{l}\text { hari } \\
3\end{array}$ & Kebutuhan buku ajar tambahan \\
\hline
\end{tabular}

Berdasarkan hasil angket guru, diperoleh informasi bahwa guru telah menyediakan sarana pengajaran berupa memberikan soal pre-test sebelum memulai pembelajaran dan melakukan post-test setelah terlaksananya kegiatan pembelajaran. Guru juga selalu memerhatikan kinerja siswa dalam proses pembelajaran seperti diskusi kelompok, menjawab soal latihan, serta sikap siswa selama proses pembelajaran berlangsung. Pada pembelajaran IPA, guru memanfaatkan beberapa sumber yaitu buku teks, modul serta LKS. Penggunaan variasi bahan ajar ini dipilih untuk memudahkan guru dalam menyampaikan materi yang akan diajarkan serta membantu guru dalam mengaitkan pembelajaran IPA dalam kehidupan sehari-hari. Namun, bahan ajar yang digunakan oleh guru belum adanya pengintegrasian pembelajaran IPA dengan kearifan lokal Jambi.

Kearifan lokal secara subtansial merupakan norma yang berlaku dalam suatu masyarakat yang diyakini kebenarannya dan menjadi acuan dalam bertindak serta berperilaku sehari-hari (Suastra \& Yasmini, 2013). Kearifan lokal merupakan bagian dari konstruksi budaya, kearifan lokal mengacu pada berbagai kekayaan budaya yang tumbuh dan berkembang dalam sebuah masyarakat yang dikenal, dipercayai, dan diakui sebagai elemen-elemen penting yang mampu mempertebal kohesi sosial di antara warga masyarakat (Masita, 2012). Kearifan lokal dalam pembelajaran IPA dipilih dengan harapan siswa akan lebih mengerti konsep-konsep IPA, bisa menerapkannya di dalam kehidupan sehari-hari, melestarikan, menghargai atau menjunjung kearifan lokal daerahnya. Berdasarkan hal tersebut, dalam pembelajaran IPA perlu adanya bahan ajar yang digunakan sebagai perantara antara materi pelajaran IPA dengan kearifan lokal masyarakat setempat seperti buku ajar. Hal ini didukung pula oleh hasil penelitian Perwitasari, Sudarmin, \& Linuwih (2016) yang menunjukkan bahwa buku ajar IPA yang terintegrasi kearifan lokal terbukti dapat meningkatkan literasi sains siswa dibandingkan dengan menggunakan buku paket biasa. 


\section{Formatif: Jurnal Ilmiah Pendidikan MIPA}

Vol. 9, No. 2, Juni 2019, pp. 151-160

p-ISSN: 2088-351X

e-ISSN: 2502-5457

DOI: http://dx.doi.org/10.30998/formatif.v9i2.3340

Kemudian untuk angket siswa terdiri dari18 butir pernyataan. Aspekyang diukur dalam angket yaitu tentang respon siswa terhadap buku ajar IPA. Berikut hasil data angket siswa pada Gambar 1.

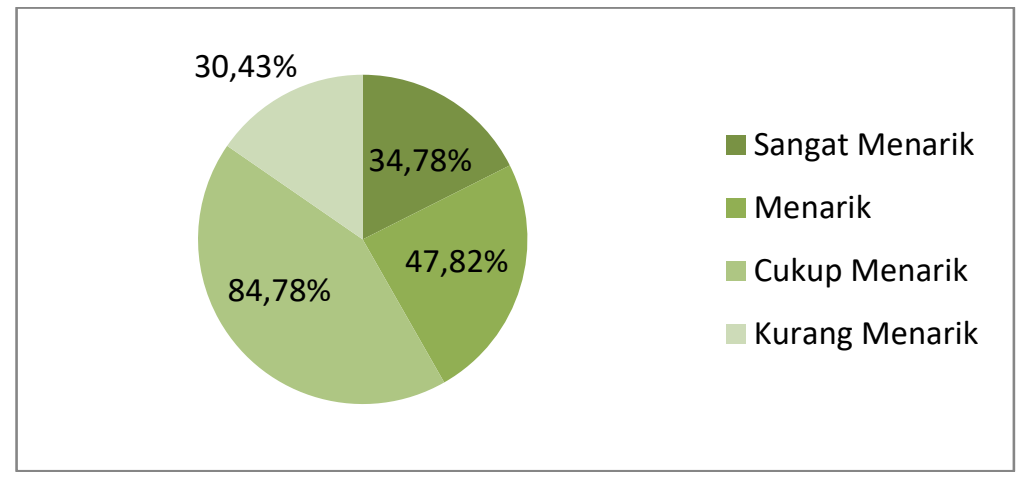

Gambar 1. Hasil Data Respon Siswa Terhadap Buku ajar IPA

Hasil angket kebutuhan pada 46 siswa Kelas VII Semester 1 SMPN 7 Muaro Jambi, menunjukkan bahwa buku ajar yang digunakan pada mata pelajaran IPA terdiri atas buku cetak dan LKS. Pemanfaatan buku ajar oleh siswa masih rendah yaitu dikarenakan buku ajar IPA yang dimiliki siswa belum cukup membantu dalam memahami materi pembelajaran. Meskipun buku ajar IPA yang ada telah mengaitkan pada kehidupan sehari-hari, tetapi buku ajar yang digunakan belum terintegrasi dengan kearifan lokal Jambi serta belum terdapatnya soal literasi sains.

Berdasarkan observasi terhadap proses pembelajaran di kelas, terlihat hanya sebagian siswa yang aktif karena kurangnya konsep dasar yang diperoleh. Walaupun siswa cukup antusias, tetapi siswa masih merasa kesulitan dalam memahami materi, siswa juga kurang termotivasi. Faktor yang menjadi kendala dalam proses pembelajaran IPA di sekolah yaitu ketersediaan buku ajar yang sesuai dengan karakter siswa, dan kebutuhan siswa dalam memahami konsep. Berdasarkan hal ini dibutuhkan buku ajar tambahan yang mampu membantu siswa dalam memahami materi, meningkatkan literasi sains siswa serta penerapannya tidak asing oleh siswa itu sendiri. Adapun buku ajar yang diharapkan siswa yaitu seperti pada gambar 2 .

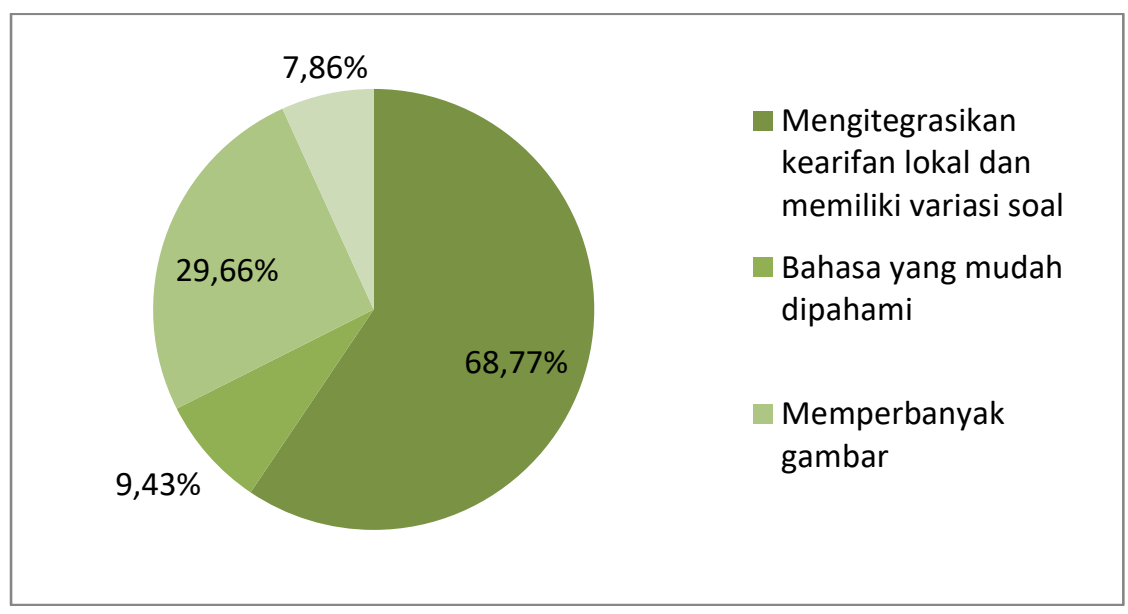

Gambar 2. Diagram Buku Ajar yang Diharapkan 
Formatif: Jurnal Ilmiah Pendidikan MIPA

Vol. 9, No. 2, Juni 2019, pp. 151-160

p-ISSN: 2088-351X

e-ISSN: 2502-5457

DOI: http://dx.doi.org/10.30998/formatif.v9i2.3340

\section{Analisis Angket Motivasi dan Sikap Siswa}

Data motivasi dan sikap siswa diperoleh dari angket studi pendahuluan yang terdiri dari 10 butir soal pernyataan motivasi dan 10 butir pernyataan sikap. Pernyataan 4 alternatif jawaban dengan skor tertinggi adalah 4 dan skor terendah adalah 1 dan jumlah responden sebanyak 48. Selain itu, motivasi dan sikap diperoleh berdasarkan observasi yang dilakukan pada saat proses pembelajaran berlangsung. Adapun aspek yang diukur dalam angket studi pendahuluan yaitu terdiri dari; (1) Saya suka belajar IPA, (2) Pembelajaran IPA dan kearifan lokal, (3) Pemecahan masalah sendiri, (4) Pembelajaran IPA membosankan. Berikut hasil data angket motivasi dan sikap siswa Gambar 3.

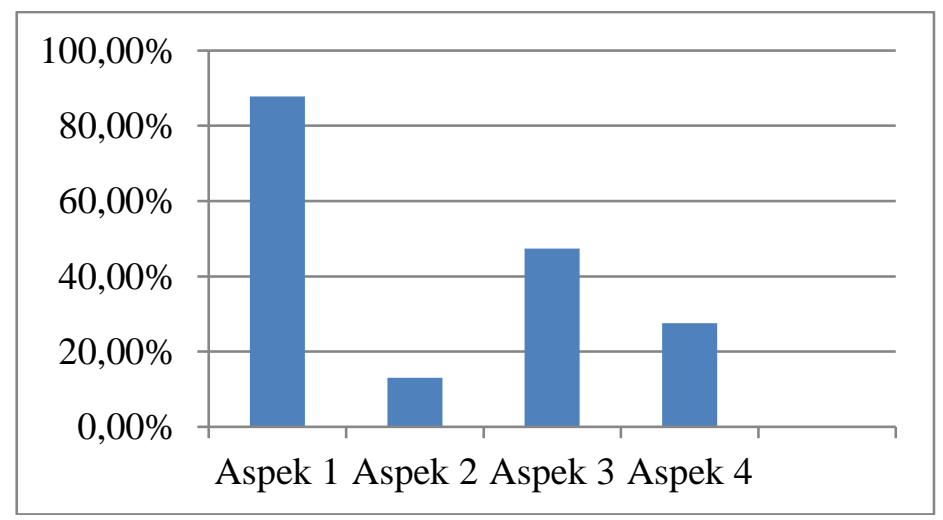

Gambar 3. Hasil Data Angket Motivasi dan Sikap Siswa

Berdasarkan gambar 3 dapat disimpulkan bahwa lebih dari sebagian siswa kelas VII SMPN 7 Muaro Jambi memiliki tingkat motivasi dan sikap belajar yang tinggi, tetapi belum berkembang secara optimal. Faktor tingginya tingkat motivasi dan sikap belajar siswa dapat dilihat dari tingkah laku siswa yaitu adanya kesungguhan siswa dalam mengerjakan tugas IPA, mendengarkan penjelasan guru dengan baik, aktif dalam pembelajaran serta mencari sumber-sumber lain yang sesuai untuk menyempurnakan tugas yang dikerjakan. Hal ini selaras dengan Uno (2008) yang menyatakan bahwa faktor tingginya tingkat motivasi dan sikap belajar siswa diukur dari beberapa aspek. Pertama adanya hasrat yang kuat untuk berhasil menguasai materi dan mendapatkan nilai yang tinggi dalam kegiatan pembelajaran. Hal ini terlihat dari adanya usaha siswa dalam menyelesaikan tugas hingga tuntas dan adanya kemauan bertanya kepada guru atau teman apabila ada pelajaran yang belum dipahami.

Kedua, adanya dorongan dan kebutuhan dalam belajar. Siswa yang berminat dalam pelajaran akan mengikuti kegiatan belajar dengan rasa senang, sehingga siswa tersebut menganggap bahwa belajar merupakan suatu kebutuhan bukan hanya suatu kewajiban. Seperti siswa kelas VII SMPN 7 Muaro Jambi berasumsi bahwa dengan belajar IPA secara berkelompok dapat lebih mudah menguasai pembelajaran lebih cepat. Ketiga, adanya harapan dan cita-cita masa depan. Harapan didasari pada keyakinan bahwa orang dipengaruhi oleh perasaan tentang gambaran hasil tindakan mereka. Hal ini terlihat dari sikap siswa kelas VII SMPN 7 Muaro Jambi yang memercayai bahwa dengan mempelajari IPA, pengetahuan mereka akan bertambah sehingga mereka dapat mengaplikasikan pembelajaran IPA dalam kehidupan sehari-hari.

Keempat, adanya penghargaan dalam belajar. Pernyataan verbal atau penghargaan dalam bentuk lainnya terhadap perilaku atau hasil belajar yang baik merupakan cara paling mudah dan efektif untuk meningkatkan motivasi belajar. Hal ini terlihat dari semangat belajar siswa. Walaupun guru tidak hadir, siswa tetap belajar mandiri supaya 


\section{Formatif: Jurnal Ilmiah Pendidikan MIPA}

Vol. 9, No. 2, Juni 2019, pp. 151-160

p-ISSN: 2088-351X

e-ISSN: 2502-5457

DOI: http://dx.doi.org/10.30998/formatif.v9i2.3340

mendapatkan pujian dari orang lain. Kelima, adanya kegiatan yang menarik dalam belajar. Hal ini terlihat dari suasana yang menarik menyebabkan proses belajar lebih bermakna seperti terlihat dari sikap siswa kelas VII SMPN 7 Muaro Jambi yang senang belajar kelompok karena melalui diskusi kelompok dapat memacu semangat siswa untuk belajar lebih giat. Keenam, adanya lingkungan belajar yang kondusif. Lingkungan belajar yang kondusif adalah salah satu faktor pendorong belajar siswa, dengan demikian siswa mampu memperoleh bantuan yang tepat dalam mengatasi kesulitan dalam belajar. Hal ini terlihat dari hasil observasi kelas VII SMPN 7 Muaro Jambi memiliki ruangan yang bersih, nyaman serta sejuk seperti yang terlihat pada gambar 4.
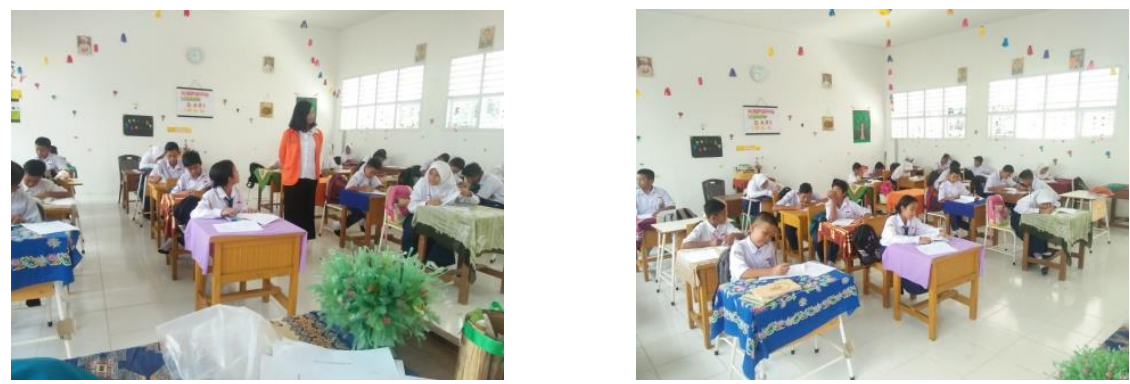

Gambar 4. Kondisi Ruang Kelas VII SMPN 7 Muaro Jambi

\section{Analisis Sarana Pendukung Pembelajaran IPA}

Berdasarkan wawancara bersama guru IPA SMPN 7 Muaro Jambi, sarana pendidikan IPA dimanfaatkan dalam proses belajar mengajar di kelas dan juga di laboratorium yaitu pada saat materi yang akan dipraktikkan dan disesuaikan dengan jadwal penggunaannya. Pemanfaatan sarana pendidikan IPA merupakan cara yang dilakukan oleh guru dalam menyampaikan materi pelajaran. Pemanfaatan sarana pendidikan IPA yang dilakukan guru sangatlah berpengaruh terhadap proses belajar mengajar diantaranya yaitu membuat siswa lebih tertarik, lebih memahami, dan lebih aktif dalam menerima materi yang disampaikan.
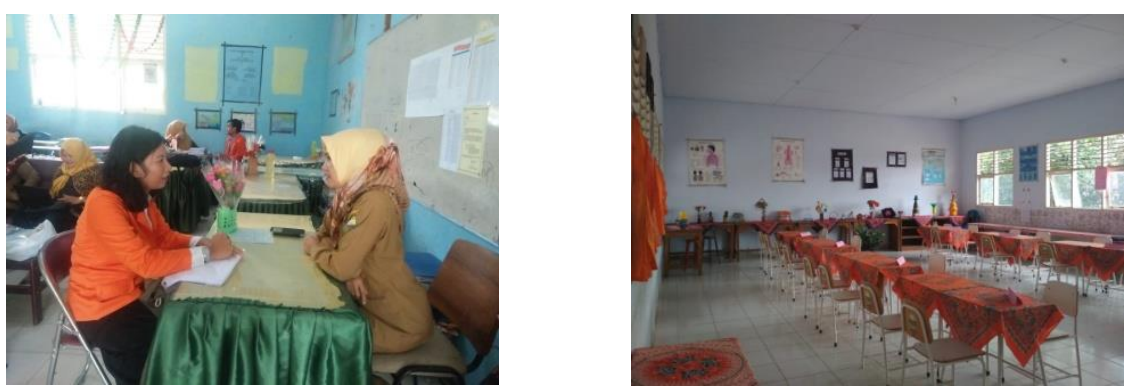

Gambar 5. (a) Wawancara guru IPA (b) Kondisi Laboratorium SMPN 7 Muaro Jambi

SMPN 7 Muaro Jambi telah menyediakan beberapa sarana pendukung dalam pembelajaran IPA yaitu disediakannya buku paket IPA yang diterbitkan oleh Kemendikbud bersifat dipinjamkan ke setiap siswa. Pemanfaatan buku paket ini terasa sangat penting karena digunakan sebagai pedoman dalam pembelajaran IPA itu sendiri. Selain itu, siswa juga ditawarkan untuk membeli buku LKS guna membantu siswa berlatih menyelesaikan permasalahan pada IPA. Selanjutnya, sarana pembelajaran IPA berupa laboratorium. SMPN 7 Muaro Jambi memiliki kelengkapan dalam hal laboratorium seperti tersedianya KIT IPA yang membantu siswa berlatih dalam mengaplikasikan pembelajaran IPA secara langsung. Berdasarkan wawancara bersama 


\section{Formatif: Jurnal Ilmiah Pendidikan MIPA}

Vol. 9, No. 2, Juni 2019, pp. 151-160

p-ISSN: 2088-351X

e-ISSN: 2502-5457

DOI: http://dx.doi.org/10.30998/formatif.v9i2.3340

guru IPA didapatkan hasil bahwa pemanfaatan KIT IPA di kelas VII SMPN 7 Muaro Jambi telah optimal digunakan. Hal ini terbukti ketika dilakukan observasi di kelas VII SMPN 7 Muaro Jambi, siswa dapat menyebutkan alat-alat yang ada pada KIT IPA dan mengetahui fungsi serta kegunaan KIT IPA.

\section{Analisis Materi yang dapat Diintegrasikan dengan Kearifan Lokal Jambi}

Pembelajaran IPA yang dapat diintegrasikan dengan kearifan lokal Jambi untuk memenuhi kebutuhan buku ajar siswa kelas VII semester I berdasarkan pemetaan kompetensi dasar yaitu sebagai berikut.

Tabel 2. Pemetaan kearifan lokal yang dapat diintegrasikan dalam KD

\begin{tabular}{|c|c|c|c|}
\hline \multicolumn{2}{|r|}{ Kompetensi Dasar } & Materi & Kearifan Lokal Jambi \\
\hline 3.1 & $\begin{array}{lr}\text { Menerapkan } & \text { konsep } \\
\text { pengukuran } & \text { berbagai } \\
\text { besaran } & \text { dengan } \\
\text { menggunakan } & \text { satuan } \\
\text { standar (baku) } & \end{array}$ & $\begin{array}{lr}\text { Objek } & \text { IPA } \\
\text { Pengamatannya }\end{array}$ & $\begin{array}{ll}\text { 1. } & \text { Tangkul } \\
\text { 2. } & \text { Geopark Merangin } \\
\text { 3. Lemang } & \\
\text { 4. } & \text { Batu Bata Setiti } \\
\text { 5. } & \text { Pasar Angso Duo } \\
& \text { Jambi } \\
\text { 6. } & \text { Tempoyak } \\
\text { 7. } & \text { Tanaman Pinang } \\
\text { 8. } & \text { Perahu Ketek } \\
\text { 9. } & \text { Kopi Liberika }\end{array}$ \\
\hline 3.4 & $\begin{array}{l}\text { Menganalisis konsep } \\
\text { suhu, pemuaian, kalor, } \\
\text { perpindahan kalor, dan } \\
\text { penerapannya dalam } \\
\text { kehidupan sehari-hari } \\
\text { termasuk mekanisme } \\
\text { menjaga kestabilan } \\
\text { suhu tubuh pada } \\
\text { manusia dan hewan }\end{array}$ & Suhu dan Perubahannya & $\begin{array}{l}\text { 1. Batik Jambi } \\
\text { 2. Gentala Arasy } \\
\text { 3. Tugu Keris Siginjai } \\
\text { 4. Pandai Besi } \\
\text { 5. Tempoyak }\end{array}$ \\
\hline 3.5 & $\begin{array}{l}\text { Menganalisis konsep } \\
\text { suhu, pemuaian, kalor, } \\
\text { perpindahan kalor, dan } \\
\text { penerapannya dalam } \\
\text { kehidupan sehari-hari } \\
\text { termasuk mekanisme } \\
\text { menjaga kestabilan } \\
\text { suhu tubuh pada } \\
\text { manusia dan hewan }\end{array}$ & $\begin{array}{l}\text { Kalor } \\
\text { Perpindahannya }\end{array}$ & $\begin{array}{ll}\text { 1. } & \text { Batu Bata Setiti } \\
\text { 2. } & \text { Pembuatan Dodol } \\
\text { 3. } & \text { Batik Jambi } \\
\text { 4. } & \text { Pesisir Tanjung Jabung } \\
\text { Barat }\end{array}$ \\
\hline
\end{tabular}

\section{PENUTUP}

Berdasarkan hasil penelitian ini dapat disimpulkan bahwa:

1. Siswa kelas VII SMPN 7 Muaro Jambi memiliki dua bahan ajar IPA yaitu buku paket dan buku LKS. Namun kedua bahan ajar ini telah belum diintegrasikan dengan kearifan lokal dan juga belum tersedia soal-soal lietrasi sains. Oleh sebab itu diharapkan adanya buku tambahan berupa buku ajar berbasis kearifan lokal Jambi 


\section{Formatif: Jurnal Ilmiah Pendidikan MIPA}

Vol. 9, No. 2, Juni 2019, pp. 151-160

p-ISSN: 2088-351X

e-ISSN: 2502-5457

DOI: http://dx.doi.org/10.30998/formatif.v9i2.3340

yang dilengkapi dengan soal-soal literasi sains yang mampu membantu siswa dalam memahami pembelajaran IPA dan peningkatan literasi sains.

2. Siswa kelas VII SMPN 7 Muaro Jambi memiliki motivasi serta sikap belajar yang tinggi dalam proses pembelajaran. Oleh karena itu, untuk mempertahankan dan meningkatkan motivasi serta sikap siswa diperlukan adanya pembelajaran bermakna seperti pengintegrasian kearifan lokal Jambi dalam pembelajaran IPA.

3. Sarana pembelajaran IPA di SMPN 7 Muaro Jambi selama ini telah mendukung proses pembelajaran. Maka dari itu jika dikembangkannya buku ajar berbasis kearifan lokal Jambi siswa dapat mempraktikkan langsung percobaan yang ada pada buku.

4. Terdapat beberapa materi IPA kelas VII Semester 1 yang dapat diintegrasikan dengan kearifan lokal Jambi diantaranya; objek IPA dan pengamatannya, suhu dan perubahannya, serta kalor dan perpindahannya.

\section{DAFTAR PUSTAKA}

Achyani, A., Rustaman, N. Y., Redjeki, S., \& Choesin, D. N. (2010). Model penulisan buku ajar biologi SMA berwawasan ekologi dan lokal untuk meningkatkan kepedulian siswa terhadap lingkungan. Bioedukasi, 1 (1).

Atmodjo, M. M. S. K. (1986). Kepribadian Budaya Bangsa (Local Genius). Jakarta: Dunia Pustaka Jaya.

Diana, S., Rachmatulloh, A., \& Rahmawati, E. S. (2015). Profil kemampuan literasi sains siswa sma berdasarkan instrumen Scientific Literacy Assesments (SLA). Seminar Nasional XII Pendidikan Biologi FKIP UNS 2015, 285-291. Bandung: Departemen Pendidikan Biologi FPMIPA UPI Bandung Indonesia

Innatesari, D. K., Setiawan, B., \& Sudibyo, E. (2015). Integrasi kearifan lokal pada tema gunung kelud terhadap kemampuan literasi sains siswa. Seminar Nasional Fisika dan Pembelajarannya 2015, 1-6. Surabaya: Program Studi S1 Pendidikan IPA Universitas Negeri Surabaya.

Istiawati, N. F. (2016). Pendidikan karakter berbasis nilai-nilai kearifan lokal adat Ammatoa dalam menumbuhkan karakter konservasi. Cendekia,10 (1): 2-3.

Martin, M. O., Mullis, I. V. S., Foy, P., \& Hooper, M. (2015). TIMSS 2015 international results in science. TIMSS.

Masita. (2012). Pendidikan karakter berbasis budaya lokal pada masyarakat muslim. Jurnal Studi Masyarakat Islam, 15 (2): 303-304.

Nofiana, M., \& Julianto, T. (2017). Profil kemampuan literasi sains siswa SMP di Kota Purwokerto ditinjau dari aspek konten, proses, dan konteks sains. Jurnal Sains Sosial dan Humaniora, 1 (2), 83-84.

Nuraini, D., Rahardjo, S. B., \& Susanti, E. (2016). Student's profile about science literacy in Surakarta. Journal of Physisics: Conference Series, http://dx.doi.org.10.1088/1742-6596/1022/1/012016.

OECD. (2016). Programme for International Assessment (PISA) Results from PISA 2015. Country Note.

OECD. (2018). PISA 2015 Results in focus. OECD Publishing.

Permana, F. S. (2015). Pengembangan Buku Ajar Biologi Berbasis Blended Learning sebagai Bekal Hidup di Abad 21 untuk Mahasiswa S1 Kimia FMIPA UM. Prosiding Seminar Nasional Pendidikan Biologi 2015, 58. Malang: FMIPA UM. 
Formatif: Jurnal Ilmiah Pendidikan MIPA

Vol. 9, No. 2, Juni 2019, pp. 151-160

p-ISSN: 2088-351X

e-ISSN: 2502-5457

DOI: http://dx.doi.org/10.30998/formatif.v9i2.3340

Perwitasari, P., Sudarmin, \& Linuwih, S. (2016). Peningkatan literasi sains melalui pembelajaran energi dan perubahannnya bermuatan etnosains pada pengasapan ikan. Jurnal Penelitian Pendidikan IPA, 1 (2), 62-70.

Sholahuddin, A. (2011). Pengembangan buku ajar kimia kelas $\mathrm{X}$ berbasis reduksi didaktik: Uji kelayakan di SMA Negeri Kota Banjarmasin. Jurnal Pendidikan dan Kebudayaan, 17 (20), 167-168.

Suastra, I. W., \& Yasmini., L. P. B. 2015. Model pembelajaran fisika untuk mengembangkan kreativitas berpikir dan karakter bangsa berbasis kearifan lokal Bali. Jurnal Pendidikan Indonesia, 2 (2), 222-223.

Suastra, I. W., \& Nengah. (2010). Science-based models of local culture to develop Basic Competence in science and value of local wisdom in junior high School. Journal of Education and The Teaching of State Univ, 1 (1), 128-132.

Sulistyorini, S. (2016). Developing SETS (science, environment, technology, and society) learning medium in lab school elementary school UNNES. International Journal of Management and Applied Science, 2 (3), 13-15.

Uno, H. B. (2008). Teori Motivasi dan Pengukurannya. Jakarta: PT. Bumi Aksara.

Yuliati, Y. (2017). Literasi sains dalam pembelajaran IPA. Jurnal Cakrawala Pendas, 3 (2), 21-28. 